\title{
INTAKE, NITROGEN BALANCE AND MICROBIAL PROTEIN SYNTHESIS OF STEERS FED WITH OR WITHOUT LIPID ADDITION
}

\author{
CONSUMO, BALANÇO DE NITROGÊNIO E SÍNTESE DE PROTEÍNA \\ MICROBIANA DE NOVILHOS ALIMENTADOS COM OU SEM ADIÇÃO DE \\ LIPÍDIOS
}

\author{
Laila Cecília Ramos BENDIA ${ }^{1}$; Carlos Augusto de Alencar FONTES $^{1 \dagger}$; \\ Elizabeth Fonsêca PROCESSI ${ }^{1}$; Clóvis Carlos SILVEIRA FILHO ${ }^{1}$; \\ Cláudio Teixeira LOMBARDI ${ }^{1}$; Paulo Roberto Silveira PIMENTEL ${ }^{2}$; \\ Ronaldo Lopes OLIVEIRA ${ }^{2}$; Leilson Rocha BEZERRA ${ }^{3}$; Tiago Cunha ROCHA ${ }^{*}$ \\ 1. State University of North Fluminense Darcy Ribeiro, Department of Animal Science, Campos dos Goytacazes, Rio de Janeiro, Brazil. \\ $\dagger$ in memoriam. 2. Federal University of Bahia, Department of Animal Science, Salvador, Bahia, Brazil; 3. Federal University of \\ Campina Grande, Center of Health and Agricultural Technology, Patos, Paraíba, Brazil; 4. State University of the Tocantina Region of \\ Maranhão, Imperatriz, Maranhão, Brazil. *tiagoticuro@yahoo.com.br
}

\begin{abstract}
This study investigated the influence of energy supplementation with or without the addition of lipids on microbial production, microbial synthesis efficiency and nitrogen balance. Eight fistulated steers were used with accessible rumens and kept in individual stalls. Their diets consisted of corn silage; corn silage + concentrate; corn silage + concentrate with addition of lipids in the form of soybean oil; and corn silage + concentrate with addition of lipids in the form of soybean grains. Estimates of microbial protein synthesis were obtained based on the urinary excretion of purine derivatives. The concentrations of ammonia in the rumen were determined immediately at 2, 4, 6 and 8 hours after feeding. The diets with concentrate increased $(\mathrm{P}<0.05)$ the microbial protein synthesis and the efficiency of the synthesis and nitrogen balance without a difference between the lipid sources $(\mathrm{P}>0.05)$. Concentrated diets presented higher concentrations of urea nitrogen in the serum and urinary urea excretion $(\mathrm{P}<0.05)$, but there was no difference between the lipid sources $(\mathrm{P}>0.05)$. Energy supplementation, with or without lipid addition, can be used as a strategy to increase the synthesis of the microbial protein in the cattle fed corn silage.
\end{abstract}

KEYWORDS: Corn silage. Nitrogen balance. Ruminal ammonia. Soybeans. Soybean oil.

\section{INTRODUCTION}

The rumen is an important component of the digestive tract of ruminants, inhabited by a dense and varied population of microorganisms, whose importance is in degrading organic matter, producing mainly volatile fatty acids, methane, carbon dioxide and microbial protein. Although there are sequestration and turnover of microorganisms in the rumen, a large proportion of the microorganisms leaves the rumen and is digested in the posterior gastrointestinal tract, supplying about 50 to $80 \%$ of the daily requirements of ruminants amino acids from the absorbed microbial protein (CPmic) in the small intestine (SNIFFEN; ROBINSON, 1987; FIRKINS; YU; MORRISON, 2007).

The amino acid composition of CPmic is similar to that found in animal products, milk and meat, and, when compared to grains, has a higher proportion of methionine and lysine, essential amino acids (ROBINSON, 2010). In view of the importance of CPmic for the protein nutrition of ruminants, we have tried to maximize the synthesis of CPmic (HACKMANN; FIRKINS, 2015), and elucidate the factors that affect it.

Evaluate the production CPmic in wide feed conditions becomes essential to identify and correct the factors that affect it, improvement the use of the nitrogen present in fodder and sources of rumen undegradable protein (RUP), since the requirements of metabolizable protein of ruminants are met by the intestinal absorption of CPmic and RUP. RUP requirements are calculated as the total protein requirement minus the CPmic amount reaching the duodenum (NRC, 1996).

The use of lipid supplementation by means of oils, oilseeds or fat bypass has a main objective to increase the energy density of the diet. However, lipid supplementation often leads to a decrease in organic matter $(\mathrm{OM})$ digestion, mainly due to a reduction in the digestion of the fibrous fraction (BENCHAAR et al., 2015) and modifications in the ruminal ecosystem (MAIA et al., 2007, WELD; ARMENTANO, 2017), which could consequently affect CPmic synthesis. 
Intake, nitrogen...

Considering the importance of CPmic for protein nutrition of ruminants, as well as the interest in adding lipid sources to the diet, this study aimed to evaluate the influence of energy supplementation and lipid addition to the supplement on microbial production and efficiency of microbial synthesis (Emic), estimated on the basis of urinary excretion of purine derivatives (PD), nitrogen balance (NB), levels of ruminal ammonia (N-NH3) and serum Nurea (NUS) and urinary excretion of urea (UEU) in confined cattle whether or not supplemented with different lipid sources, in the form of milled soybeans or soybean oil.

\section{MATERIAL AND METHODS}

\section{Location and ethical considerations}

This study was approved by the Research Ethics Committee of the State University of North Fluminense, protocol number 168/12. The experiment was carried out at the Animal Husbandry Research Support Unit, the Animal Science and Animal Nutrition Laboratory of the Northern Fluminense State University - Darcy Ribeiro (UENF), Campos dos Goytacazes, RJ.

Animals, experimental treatments and diets

Eight rumen-fistulated crossbred steers with an average initial body weight of $300 \mathrm{~kg}$ were used and kept in individual, partially covered stalls with concrete floors, drinking fountains and a feeders. The animals were vermifuged and submitted a pre-
BENDIA, L. C. R. et al.

experimental period for adaptation to experimental facilities and conditions. During this period, all the animals received the same feed, consisting of corn silage and a concentrated ration containing corn and soybean meal.

After the adaptation period, the animals were randomly assigned to two $4 \times 4$ balanced Latin squares, comprising four animals, four diets and four periods, which were conducted simultaneously.

The diets comprised the following:

$\mathrm{CS}$ - Corn silage;

$\mathrm{CS}+\mathrm{C}-70 \%$ corn silage and $30 \%$ concentrate;

$\mathrm{CS}+\mathrm{SO}-70 \%$ corn silage and $30 \%$ concentrate containing 5\% lipids from soybean oil;

$\mathrm{CS}+\mathrm{SG}-70 \%$ of corn silage and $30 \%$ of concentrate, containing $5 \%$ of lipids derived from soybean grains.

Feeding was done twice a day in equal portions at 8:00 am and 4:00 p.m. in the form of a total mixed ration, aiming to keep leftovers at approximately $5 \%$ to guarantee ad libitum feed intake. The concentrate was manually mixed into the silage at the time of feeding. The intake was obtained by the difference between the supplied feed and the leftovers, with the leftovers being weighed daily and $10 \%$ of their sampled weight being used for further analysis. Table 1 shows the proportion of the ingredients and the composition of the experimental diets.

Table 1. Ingredients and chemical composition of the supplements and pasture

\begin{tabular}{lllll}
\hline \multicolumn{1}{c}{ Composition } & \multicolumn{3}{c}{ Diets } \\
\cline { 2 - 5 } & CS & CS+C & CS+SO & CS+SG \\
\hline Corn silage & 100 & 70.0 & 70.0 & 70.0 \\
Soybean grains & & & & 16.4 \\
Corn & & 16.9 & 13.1 & 13.0 \\
Soybean Oil & & & 3.10 & \\
Limestone & & 0.59 & 0.57 & 0.55 \\
Soybean meal & 12.5 & 13.2 & \\
Nutrient & DM basis (\%DM) & & & \\
Dry matter (g/kg as fed) & 31.6 & 46.9 & 48.8 & 47.4 \\
Organic matter & 84.5 & 85.5 & 85.7 & 85.9 \\
Crude protein & 6.95 & 12.6 & 12.0 & 12.2 \\
Ether extract & 1.60 & 1.77 & 5.00 & 5.00 \\
NDF $^{1}$ & 54.2 & 40.5 & 41.4 & 39.9 \\
\hline
\end{tabular}

${ }^{\mathrm{I}}$ Neutral detergent fiber

\section{Collections, blood sampling and laboratory analyses}

The experimental periods lasted eighteen days, with the first fourteen days used for the adaptation of the animals and the data collections performed in the last four days.

At the beginning of each collection period, the animals were weighed, and blood was collected. Blood samples were obtained four hours after the 
Intake, nitrogen...

morning feeding via puncture of the jugular vein using test tubes. The blood samples were immediately centrifuged at $5,000 \mathrm{rpm}$ for 15 minutes, and the blood serum was obtained and stored at $-15^{\circ} \mathrm{C}$ for further analysis of serum urea.

On the 16th and 17th day of each experimental period, the total urine and feces for 24 hours were collected. Urine collections performed in the 24-hour period were obtained using collector funnels adapted to the animals. Rubber hoses were coupled to the funnels and led the urine into plastic containers containing $200 \mathrm{~mL}$ of $20 \%$ sulfuric acid solution $\left(\mathrm{H}_{2} \mathrm{SO}_{4}\right)$. At the end of each 24-hour period, the produced urine was properly measured, homogenized and filtered on filter paper. Then, two urine samples were obtained: one with a volume of $10 \mathrm{~mL}$ diluted with $40 \mathrm{~mL}$ of sulfuric acid $\left(\mathrm{H}_{2} \mathrm{SO}_{4}\right)$ and the other, an undiluted sample of approximately $50 \mathrm{~mL}$. Both of the samples were identified and stored in plastic bottles at $-15^{\circ} \mathrm{C}$ for further creatinine, urea, allantoin and uric acid analysis.

Simultaneously, the urine samples were collected. Feces samples obtained by spontaneous defecation were collected and stored in plastic bags. At the end of each 24-hour period, the samples were weighed, homogenized, and samples corresponding to $20 \%$ of the total weight were taken, which were pre-dried in a forced ventilation oven at $65^{\circ} \mathrm{C}$ and stored for further analysis of the $\mathrm{N}$ in the feces.

On the 18th day, ruminal fluid samples were collected for the determination of the ruminal ammonia nitrogen $\left(\mathrm{N}-\mathrm{NH}_{3}\right)$ concentrations, before the morning ration and two, four, six and eight hours after. The ruminal liquid samples, after collection, were filtered in a triple layer of cheesecloth and stored in plastic flasks containing 1 $\mathrm{mL}$ of sulfuric acid solution $(1: 1)$ at $-20^{\circ} \mathrm{C}$ for further determination of $\mathrm{N}-\mathrm{NH}_{3}$ by distillation with potassium hydroxide $(\mathrm{KOH}) 2 \mathrm{~N}$, according to the technique described by Vieira (1980).

Estimates of the microbial nitrogen flux were obtained by purine intestinal absorption (X, $\mathrm{mmol} /$ day), estimated based on the excretion of purine derivatives ( $\mathrm{Y}, \mathrm{mmol} /$ day) and metabolic weight (PV 0.75) according to the following equation (VERBIC et al., 1990):

$\mathrm{X}=\frac{\mathrm{Y}-0.385 \mathrm{PV}^{\wedge} 0.75}{0.85}$

Where 0.85 is the recovery of the purines absorbed as urine purine derivatives, and 0.385 $\mathrm{PV}^{0.75}$ corresponds to the endogenous contribution to urine excretion.
BENDIA, L. C. R. et al.

The intestinal flow of the microbial nitrogenous compounds (N) (Y, mmol/day) was estimated as a function of the absorbed microbial purines (X, mmol/day) using the following equation (CHEN; GOMES, 1992):

$\mathrm{Y}=\frac{70 \mathrm{X}}{0.83 * 0.116 * 1000}$

Where in 70 represents the $\mathrm{N}$ content in the purines (mg N. $\mathrm{mmol}^{-1}$ ); 0.83 corresponds to the digestibility of the microbial purines; and 0.116 is the N-RNA:N ratio in the bacteria.

The urinary volume (L), estimated from the spot samples, was calculated from the creatinine concentration in the urine spot sample $(\mathrm{mg} / \mathrm{L})$, and the amount of creatinine excreted daily in $\mathrm{mg} / \mathrm{kgBW}$ was:

$\operatorname{Vol}(\mathrm{L})=\frac{\mathrm{BW}(\mathrm{Kg}) * \text { creatinine excreted }\left(\mathrm{mg} \cdot \mathrm{KgBW}^{-1}\right)}{\text { creatinine concentration }\left(\mathrm{mg} \cdot \mathrm{L}^{-1}\right)}$

For comparison purposes, the daily creatinine (EC) excretions were estimated in three ways:

-From the product of the total volume and creatinine concentration of the total collection;

-By means of the equations proposed in the literature:

-Chizzotti, Valadares Filho and Valadares (2004):

$\mathrm{CE}(\mathrm{mg} / \mathrm{kgBW})=32,27-0,01093 \mathrm{BW}$

-Silva et al. (2012):

\section{$C E($ g/day $)=0,0345 * B W^{0.9491}$}

Analyses of the plasma urea, creatinine, uric acid, and urine urea were performed using commercial kits (LABTEST; LAGOA SANTA, MINAS GERAIS, BRASIL), according to the manufacturer's guidelines. The analysis of allantoin in the urine was done using the colorimetric method proposed by Fujihara et al. (1987), as described by Chen and Gomes (1992).

Food, leftovers, and feces samples were evaluated for DM (967.03, AOAC, 1990), organic matter (OM), PB (981.10, AOAC, 1990), ethereal extract (EE) (920.29, AOAC, 1990), and neutral detergent fibers (NDF) (Mertens, 2002).

\section{Statistical analysis}

Statistical analyses of daily urinary excretion of allantoin, uric acid, purine derivatives, 
and urea, as well as the daily absorptions of purine derivatives, microbial nitrogen compounds and microbial efficiency, were performed using the SAS Proc Mixed Procedure for repeated measurements (day aligned in period). The model included the effects of the Latin square, diet, period, day within the period, the diet $\mathrm{x}$ Latin square and Latin square $\mathrm{x}$ period interactions.

The AR (1) and composite symmetry (CS) covariance structures were tested, using the AR (1) structure, based on the information criteria: AIC, AICC, BIC and -2 Res Log Likelihood.

\section{RESULTS AND DISCUSSION}

Contrast $\mathrm{C} 1$ indicated that the ALA, UA, DP, Pabs, Nmic, RDCHO and Emic of the SM treatment were lower than the other diets $(\mathrm{P}<0.01)$ (Table 2).

Table 2. Mean, standard error (SEM) and probability levels for excretions of allantoin (ALA), uric acid (UA), purine derivatives (PD) obtained in total urine collection, absorbed purines (Pabs), percentage of allantoin (ALA/DP) in PD, microbial nitrogen (Nmic), rumen degraded carbohydrates (RDCHO), and microbial efficiency (Emic) for cattle supplemented or not supplemented with different lipid sources.

\begin{tabular}{|c|c|c|c|c|c|c|c|c|}
\hline \multirow{2}{*}{ Variables } & \multicolumn{4}{|l|}{ Diets } & \multirow{2}{*}{ SEM } & \multicolumn{3}{|c|}{ Contrasts } \\
\hline & $\mathrm{CS}$ & $\mathrm{CS}+\mathrm{C}$ & $\mathrm{CS}+\mathrm{SO}$ & $\mathrm{CS}+\mathrm{SG}$ & & $\mathrm{C} 1$ & $\mathrm{C} 2$ & $\mathrm{C} 3$ \\
\hline & $\mathrm{mmol} / \mathrm{day}$ & & & & & & & \\
\hline ALA & 59.3 & 83.2 & 87.0 & 80.9 & 3.28 & $<0.01$ & 0.84 & 0.16 \\
\hline UA & 6.6 & 11.4 & 10.2 & 10.4 & 0.98 & $<0.01$ & 0.30 & 0.89 \\
\hline PD & 66.7 & 94.8 & 96.8 & 91.5 & 3.52 & $<0.01$ & 0.88 & 0.24 \\
\hline Pabs & 42.3 & 76.4 & 78.2 & 72.7 & 4.27 & $<0.01$ & 0.84 & 0.31 \\
\hline & $\%$ & & & & & & & \\
\hline ALA/PD & $\begin{array}{l}89.4 \\
\text { g/day }\end{array}$ & 88.2 & 89.5 & 88.5 & 1.03 & 0.45 & 0.34 & 0.36 \\
\hline Nmic & $\begin{array}{l}30.3 \\
\mathrm{~kg} / \text { day }\end{array}$ & 55.2 & 57.4 & 52.2 & 2.64 & $<0.01$ & 0.89 & 0.15 \\
\hline RDCHO & 1.72 & 2.61 & 2.38 & 2.35 & 0.13 & $<0.01$ & 0.15 & 0.88 \\
\hline Emic $^{1}$ & 17.6 & 21.2 & 24.6 & 22.3 & 1.25 & 0.02 & 0.14 & 0.18 \\
\hline
\end{tabular}

$\mathrm{C} 1=\mathrm{CS}$ vs other diets; $\mathrm{C} 2=\mathrm{CS}+\mathrm{C}$ vs $\mathrm{CS}+\mathrm{SO}$ e $\mathrm{CS}+\mathrm{SG}, \mathrm{C} 3=\mathrm{CS}+\mathrm{SO}$ vs $\mathrm{CS}+\mathrm{GS}$.

${ }^{1} \mathrm{gNmic} / \mathrm{kg} \mathrm{RDCHO}$.

The differences observed in this experiment are possibly related to differences in the rate of microbial synthesis between the diets. According to Verbic et al. (1990), when the excretion of PD is above $35 \mathrm{mmol} / \mathrm{day}$, the excretion of PD in the urine would be linearly correlated with the uptake of microbial nucleic acids.

However, there was no difference $(\mathrm{P}>0.05)$ in the ALA/PD ratio between the diets, with values between 88.16 and $89.53 \%$. The contribution of allantoin to the total excreted urine has been shown to be constant both in steers (VERBIC et al., 1990) and in cows (VAGNONI et al., 1997), independent of purine flow.

The availability of energy and nitrogen are the main dietary factors limiting microbial synthesis. Thus, higher Nmic syntheses observed for the $\mathrm{CS}+\mathrm{C}, \mathrm{CS}+\mathrm{SO}$ and $\mathrm{CS}+\mathrm{SG}$ diets in relation to the CS can be attributed to the higher observed intakes of organic matter $(\mathrm{P}<0.01)$ and protein $(\mathrm{P}<0.01)$, as indicated by the $\mathrm{C} 1$ contrast (Table 3$)$.

Table 3. Mean, standard error (SD) and probability levels for dry matter intake (IDM), organic matter intake (IOM), crude protein intake (ICP), ethereal extract intake (IEE), neutral detergent fiber intake (INDF) for cattle supplemented or not supplemented with different lipid sources.

\begin{tabular}{|c|c|c|c|c|c|c|c|c|}
\hline \multirow{2}{*}{ Variables } & \multicolumn{4}{|c|}{ Diets } & \multirow{2}{*}{ SEM } & \multicolumn{3}{|c|}{ Contrasts } \\
\hline & $\mathrm{CS}$ & $\mathrm{CS}+\mathrm{C}$ & $\mathrm{CS}+\mathrm{SO}$ & $\mathrm{CS}+\mathrm{SG}$ & & $\mathrm{C} 1$ & $\mathrm{C} 2$ & $\mathrm{C} 3$ \\
\hline IDM & 5.47 & 7.97 & 7.47 & 7.36 & 0.44 & $<0.01$ & 0.31 & 0.86 \\
\hline IOM & 4.95 & 7.33 & 6.86 & 6.83 & 0.15 & $<0.01$ & 0.33 & 0.95 \\
\hline ICP & 0.33 & 0.93 & 0.87 & 0.84 & 0.04 & $<0.01$ & 0.16 & 0.71 \\
\hline IEE & 0.07 & 0.14 & 0.37 & 0.36 & 0.01 & $<0.01$ & $<0.01$ & 0.69 \\
\hline INDF & 3.08 & 3.31 & 3.13 & 3.02 & 0.20 & 0.74 & 0.35 & 0.70 \\
\hline
\end{tabular}

$\mathrm{C} 1=\mathrm{CS}$ vs other diets; $\mathrm{C} 2=\mathrm{CS}+\mathrm{C}$ vs $\mathrm{CS}+\mathrm{SO}$ e $\mathrm{CS}+\mathrm{SG}, \mathrm{C} 3=\mathrm{CS}+\mathrm{OS}$ vs $\mathrm{CS}+\mathrm{SG}$. 
Thus, the higher Nmic and Emic syntheses observed for the energy supplementation diets (CS + $\mathrm{C}, \mathrm{CS}+\mathrm{SO}$ and $\mathrm{CS}+\mathrm{SG}$ ) may be attributed in part to higher energy availability and a more uniform pattern throughout the day. Then, diets based on silage were supplemented with concentrate, which correlated with higher food intake in these diets (Table 3).

Increased intake provides a higher rate of passage, reducing the retention time of microorganisms in the rumen and the maintenance cost of these microorganisms. Thus, the highest dry matter intake $(\mathrm{P}<0.01)$ for the $\mathrm{CS}+\mathrm{C}, \mathrm{CS}+\mathrm{SO}$ and $\mathrm{CS}+\mathrm{SG}$ treatments in relation to $\mathrm{CS}$ as indicated by contrast $\mathrm{C} 1$ (Table 3), may have increased (PIRT, 1965), making it possible to use energy more efficiently for growth and, consequently, producing higher Emic in these treatments.

The concentrations of $\mathrm{N}^{-\mathrm{NH}_{3}}$ were influenced quadratically by the collection times (Table 4). The maximum concentrations estimated were 8.22 at $3.20,17.14$ at $2.10,12.25$ at 1.84 and $13.05 \mathrm{mg} / \mathrm{dL}$ at 2.62 hours after feeding for the CS, $\mathrm{CS}+\mathrm{C}, \mathrm{CS}+\mathrm{SO}$ and $\mathrm{CS}+\mathrm{SG}$, respectively.

Table 4. Mean, regression, coefficients of determination (R2), and variation (CV) obtained as a function of ammonia concentrations.

\begin{tabular}{lllll}
\hline Diets & {$\left[\mathrm{NH}_{3}\right]^{1}$} & Regression & $\mathrm{R}^{2}$ & $\mathrm{CV} \%$ \\
\hline $\mathrm{CS}$ & $7.13 \mathrm{a}$ & $\hat{\mathrm{Y}}=6,8642+0,8452 * \mathrm{X}-0,1318^{*} \mathrm{X}^{2}$ & 0.42 & 29.2 \\
$\mathrm{CS}+\mathrm{C}$ & $13.5 \mathrm{c}$ & $\hat{\mathrm{Y}}=16,0244+1,0575 \mathrm{X}-0,2510^{*} \mathrm{X}^{2}$ & 0.56 & 29.1 \\
$\mathrm{CS}+\mathrm{SO}$ & $9.90 \mathrm{~b}$ & $\hat{\mathrm{Y}}=11,6636+0,6470 \mathrm{X}-0,1758^{*} \mathrm{X}^{2}$ & 0.42 & 36.0 \\
$\mathrm{CS}+\mathrm{SG}$ & $11.1 \mathrm{~b}$ & $\hat{\mathrm{Y}}=10,9301+1,5873 * \mathrm{X}-0,3049^{*} \mathrm{X}^{2}$ & 0.52 & 28.6 \\
\hline
\end{tabular}

${ }^{1}$ Values followed with different letters in the column differ from each other by the Confidence Interval at $95 \%$ probability.

* Significant at the $5 \%$ probability level by the t-test.

The quadratic behavior of ammonia concentration agrees with previous observations, where the maximum values were approximately 2 to 3 hours after the feeding (SOUZA et al., 2009). The maximum ammonia concentration in the CS treatment was obtained only 3.02 hours after feeding, a value close to that observed by Cabral et al. (2008) at 3.55 hours. However, the protein degradation in the rumen depends not only on protein solubility but also on the proteolytic activity of rumen microorganisms. The proliferation of amylolytic ruminal microorganisms, known to be more proteolytic than cellulolytics, is stimulated by cereal-based diets (SIDDONS; PARADINE, 1981). In this way, the proteolytic activity of the microorganisms seems to be the most logical explanation for the observed differences between the diets.

The lowest estimated ammonia concentration (Table 4) was observed for the CS diet; however, it was higher than the minimum value of $5.0 \mathrm{mg} / \mathrm{dL}$ that was required for maximum Nmic synthesis (SATTER; SLYTER, 1974). In this way, it can be inferred that the microbial synthesis for the CS diet was limited by the energy availability associated with the fact that the animals in this treatment had lower crude protein intake.

As indicated by contrast $\mathrm{C} 2$ (Table 3 ), the $\mathrm{CS}+\mathrm{C}$ treatment did not differ $(\mathrm{P}=0.16)$ from the lipid addition treatments $(\mathrm{CS}+\mathrm{SO}$ and $\mathrm{CS}+\mathrm{SG})$ in relation to the protein intake, but there was a significant difference $(\mathrm{P}<0.05)$ in the concentration of ammonia, with a lower concentration observed for the treatments with lipid addition $(\mathrm{P}<0.05)$ compared to the CS $+\mathrm{C}$ treatment (Table 4).

In this experiment, there was no difference in the Nmic synthesis $(\mathrm{P}=0.89)$ between the $\mathrm{CS}+\mathrm{C}$ diet in relation to $\mathrm{CS}+\mathrm{SO}$ and $\mathrm{CS}+\mathrm{SG}$. Consequently, variations in the ruminal ammonia concentration can be attributed to modifications in the degradation of nitrogenous compounds and dietary and microbial proteins in the rumen. The effects of lipids on dietary protein degradation in the rumen are not yet clear, as decreases (JENKINS; FOTOUHI, 1990), increases (BEN SALEM et al. 1993) and an absence of effect (DOREAU; LEGAY; BAUCHART, 1991) have been reported.

There was no observed effect of lipid addition $(P=0.14)$ or the way lipids were added to diets $(P=0.18)$ on Emic, as indicated by the $\mathrm{C} 2$ and C3 contrasts, respectively (Table 2 ). However, it is worth mentioning that, in the present experiment, the amount of carbohydrates degraded in the rumen (RDCHO), which are used to calculate the Emic, was obtained by means of estimation using equations proposed by Sniffen et al. (1992). As the aforementioned equations do not consider a possible reduction in carbohydrate degradation in the rumen, due to the addition of lipids, which may increase the estimated value of Emic, the Emic values found for the lipid addition treatments may have been underestimated. However, the amount of Nmic reaching the duodenum was not affected by the addition of lipids in this study, which is a more 
Intake, nitrogen...

reliable indicator of the amount of microbial protein synthesized compared to Emic.

The mean values observed for urinary excretion of urea (UEU), serum N-urea (NUS), Ningested, $\mathrm{N}$-urine, $\mathrm{N}$-feces and nitrogen balance
BENDIA, L. C. R. et al.

(NB) are shown in Table 5. As indicated by contrast $\mathrm{C} 1$, lower concentrations of NUS $(\mathrm{P}<0.01)$ and UEU $(\mathrm{P}<0.01)$ were observed in animals that received the $\mathrm{CS}$ diet in relation to those that received $\mathrm{CS}+\mathrm{C}, \mathrm{CS}+\mathrm{SO}$ and $\mathrm{CS}+\mathrm{SG}$ treatments.

Table 5. Mean, standard error (SD) and probability levels for urinary excretion of urea (UEU), serum N-urea (NUS), N-ingested, N-urine, $\mathrm{N}$-feces and nitrogen balance for cattle supplemented or not supplemented with different lipid sources.

\begin{tabular}{|c|c|c|c|c|c|c|c|c|}
\hline \multirow{2}{*}{ Variables } & \multicolumn{4}{|l|}{ Diets } & \multirow{2}{*}{ SEM } & \multicolumn{3}{|c|}{ Contrasts } \\
\hline & CS & $\mathrm{CS}+\mathrm{C}$ & $\mathrm{CS}+\mathrm{SO}$ & $\mathrm{CS}+\mathrm{SG}$ & & C1 & $\mathrm{C} 2$ & C3 \\
\hline NUS & $\begin{array}{l}\mathrm{mg} / \mathrm{dL} \\
5.28 \\
\mathrm{mg} / \mathrm{kg} / \mathrm{BW}\end{array}$ & 11.4 & 14.5 & 12.5 & 0.89 & $<0.01$ & 0.44 & 0.79 \\
\hline UEU & $\begin{array}{l}17.2 \\
\text { g/day }\end{array}$ & 148 & 157 & 162 & 14.9 & $<0.01$ & 0.06 & 0.12 \\
\hline $\mathrm{N}$-ingested & 52.8 & 149 & 139 & 134 & 5.78 & $<0.01$ & 0.22 & 0.33 \\
\hline $\mathrm{N}$-urine & 29.2 & 74.5 & 63.6 & 72.9 & 3.86 & $<0.01$ & 0.17 & 0.77 \\
\hline $\mathrm{N}$-feces & 14.3 & 36.6 & 47.1 & 37.0 & 3.42 & $<0.01$ & 0.24 & 0.09 \\
\hline NB & 9.30 & 37.9 & 28.3 & 24.2 & 4.78 & $<0.01$ & 0.84 & 0.31 \\
\hline
\end{tabular}

$\mathrm{C} 1=\mathrm{CS}$ vs other diets; $\mathrm{C} 2=\mathrm{CS}+\mathrm{C}$ vs $\mathrm{CS}+\mathrm{SO}$ e $\mathrm{CS}+\mathrm{SG}, \mathrm{C} 3=\mathrm{CS}+\mathrm{SO}$ vs $\mathrm{CS}+\mathrm{SG}$.

There was consensus that there is a positive correlation between the concentrations of NUS and UEU (KOHN; DINNEEN; RUSSEK-COHEN, 2005), which are influenced by the percentage of CP in the diet and the nitrogen intake (VAN SOEST, 1994). Thus, the lower CP percentage in the diet and the lower amount of ingested $\mathrm{N}$ observed for the SM diet provided lower concentrations of NUS and UEU.

The CS $+\mathrm{C}$ treatment did not differ from the treatments with lipid addition, namely, $\mathrm{CS}+\mathrm{SO}$ and $\mathrm{CS}+\mathrm{SG}$, in relation to the concentration of NUS $(\mathrm{P}=0.44)$ and UEU $(\mathrm{P}=0.06)$, as indicated by the $\mathrm{C} 2$ contrast (Table 5). Although significant, differences in the rumen ammonia concentration were small, namely, 3.64 and $2.6 \mathrm{mg} / \mathrm{dL}$ for the CS $+\mathrm{SO}$ and $\mathrm{CS}+\mathrm{SG}$ treatments, respectively, in relation to the $\mathrm{CS}+\mathrm{C}$ treatment. Therefore, differences may not have been detected for the NUS concentrations between CS $+\mathrm{C}$ treatment and those with lipid addition $(\mathrm{CS}+\mathrm{SO}$ and $\mathrm{CS}+\mathrm{SG})$.

Excretions of urinary $(\mathrm{P}<0.01)$ and fecal nitrogen $(\mathrm{P}<0.01)$ increased with the inclusion of concentrate in the diet; however, these presented higher $\mathrm{NB}$, as indicated by the $\mathrm{C} 1$ contrast. According to Yan et al. (2007), the intake, excretion, and the amount of nitrogen retained are positively related to the intake of dry matter and energy and negatively related to the proportion of forage.

There was no difference in the urine $(\mathrm{P}=0.17)$ and feces nitrogen excretions $(\mathrm{P}=0.24)$, as well as for NB ( $\mathrm{P}>0.05)$, between the $\mathrm{CS}+\mathrm{C}$ diet and the diets with lipid addition as indicated by contrast C2. Despite the 3.64 and $2.46 \mathrm{mg} / \mathrm{dL}$ observed reductions in the rumen ammonia concentrations for the $\mathrm{CS}+\mathrm{SO}$ and $\mathrm{CS}+\mathrm{SG}$ diets, respectively, in relation to the $\mathrm{CS}+\mathrm{C}$ diet, there was no difference in the reduction in $\mathrm{N}$ excretion in the urine compared to the $\mathrm{CS}+\mathrm{C}$ diet, with urine being the main form of nitrogen excretion observed for all the diets.

For there to be a difference in the nitrogen retention changes, the nitrogen excretion in the urine should be accompanied by a reduction or maintenance in the amount of nitrogen excreted in the feces and vice versa, so that changes in the nitrogen excretion pathway do not result in changes in $\mathrm{BN}$.

Although there was an increase in nitrogen excretion when supplementation was added, and there was no influence of lipid addition, which was higher for supplemented animals, NB was positive in all the diets, indicating adequate protein and energy balance in diets and the absence of the mobilization of body reserves, even for diets consisting only of corn silage.

\section{CONCLUSION}

Energy supplementation, with or without lipid addition, can be used as a strategy to increase the synthesis of microbial protein in cattle fed a corn silage diet. 
RESUMO: Este estudo investigou a influência da suplementação energética com ou sem adição de lipídios na produção microbiana, eficiência de síntese microbiana e balanço de nitrogênio. Oito novilhos fistulados foram utilizados com rúmen acessível e mantidos em baias individuais. Suas dietas consistiram de silagem de milho; silagem de milho + concentrado; silagem de milho + concentrado com adição de lipídios na forma de óleo de soja; e silagem de milho + concentrado com adição de lipídios na forma de grãos de soja. Estimativas de síntese de proteína microbiana foram obtidas com base na excreção urinária de derivados de purina. As concentrações de amônia no rúmen foram determinadas imediatamente às $2,4,6$ e 8 horas após a alimentação. As dietas com concentrado aumentaram $(\mathrm{P}<0,05)$ a síntese de proteína microbiana e a eficiência da síntese e o balanço de nitrogênio sem diferença entre as fontes lipídicas $(\mathrm{P}>0,05)$. As dietas concentradas apresentaram maiores concentrações de nitrogênio uréico no soro e excreção urinária de uréia $(\mathrm{P}<0,05)$, mas não houve diferença entre as fontes lipídicas $(\mathrm{P}>0,05)$. A suplementação energética, com ou sem adição de lipídios, pode ser utilizada como estratégia para aumentar a síntese da proteína microbiana em bovinos alimentados com silagem de milho.

PALAVRAS-CHAVE: Amônia ruminal. Balanço de nitrogênio. Óleo de soja. Silagem de milho. Soja.

\section{REFERENCES}

AOAC Official Analytical Chemists. 15.ed. Association of official methods of analysis, Washington, DC, USA, 1990.

BEN SALEM, H.; KRZEMINSKI, R.; FERLAY, A.; DOREAU, M. Effect of lipid supply on in vivo digestion in cows: comparison of hayand corn-silage diets. Canadian Journal of Animal Science, v. 73, p. 547-557, 1993. http://dx.doi.org/doi:10.4141/cjas93-059

BENCHAAR, C.; HASSANAT, F.; MARTNEAU, R.; GERVAIS, R. Linseed oil supplementation to dairy cows fed diets based on red clover silage or corn silage: Effects on methane production, rumen fermentation, nutrient digestibility, $\mathrm{N}$ balance, and milk production. Journal of dairy science, v. 98, n. 11, p. 7993-8008, 2015. http://dx.doi.org/doi:10.3168/jds.2015-9398

CABRAL, L. S. C.; VALADARES FILHO, S. C.; DETMANN, E.; ZERVOUDAKIS, J. T.; SOUZA, A. L.; VELOSO, R. G. Microbial efficiency and ruminal parameters in cattle fed diets based on tropical forage. Brazilian Journal of Animal Science, v.37, n.5, p.919-925, 2008. http://dx.doi.org/doi:10.1590/S151635982008000500021

CHEN, X. B.; GOMES, M. J. Estimation of microbial protein supply to sheep and cattle based on urinary excretion of purine derivatives - an overview of technical details. Bucksburnd: Rowett Research Institute, International Feed Resources Unit, 1992, 21p.

CHIZZOTTI, M. L.; VALADARES FILHO, S. C.; VALADARES, R. F. D. Excreção de creatinina em novilhos e novilhas. In: REUNIÃO ANUAL DA SOCIEDADE BRASILEIRA DE ZOOTECNIA, 41., 2004, Campo Grande. Anais...Campo Grande:2004. (CD-ROM).

DOREAU, M.; LEGAY, F.; BAUCHART, D. Effect of source and level of supplemental fato on total and ruminal organic matter and nitrogen digestion in dairy cows. Journal Dairy Science. v. 74, p. 2233-2242, 1991. http://dx.doi.org/doi:10.3168/jds.S0022-0302(91)78396-3

FIRKINS, J. L.; YU, Z.; MORRISON, M. Ruminal nitrogen metabolism: perspectives for integration of microbiology and nutrition for dairy. Journal of Dairy Science, v. 90, p. 1-16, 2007. http://dx.doi.org/doi:10.3168/jds.2006-518

FUJIHARA, T.; ORSKOV, E. R.; REEDS, P. J.; KYLE, D. J. The effect of protein infusion on urinary excretion of purine derivatives in ruminants nourished by intragastric nutrition. Journal of Agricultural Science, v. 109, p 7-12, 1987. http://dx.doi.org/doi:10.1017/S0021859600080916 
Intake, nitrogen...

BENDIA, L. C. R. et al.

HACKMANN, T. J.; FIRKINS, J. L. Maximizing efficiency of rumen microbial protein production. Frontiers in microbiology, v. 6, p. 465, 2015. http://dx.doi.org/doi:10.3389/fmicb.2015.00465

JENKINS, T. C.; FOTOUHI, N. Effects of lecithin and corn oil on site of digestion, ruminal fermentation and microbial protein synthesis in sheep. Journal Animal Science, v. 68, p. 460-466, 1990.

http://dx.doi.org/doi:10.2527/1990.682460x

KOHN, R. A.; DINNEEN, M. M.; RUSSEK-COHEN, E. Using blood urea nitrogen to predict nitrogen excretion and efficiency of nitrogen utilization in cattle, sheep, goats, horses, pigs, and rats. Journal Animal Science. v. 83, p. 879-889, 2005. http://dx.doi.org/doi:10.2527/2005.834879x

MAIA, M. R.; CHAUDHARY, L. C.; FIGUERES, L.; WALLACE, R. J. Metabolism of polyunsaturated fatty acids and their toxicity to the microflora of the rumen. Antonie Van Leeuwenhoek, v. 91, n.4, p. 303-314, 2007. http://dx.doi.org/doi:10.1007/s10482-006-9118-2

NRC - Nutrient Requirements of Beef Cattle, National Academy Press, National Research Council, Washington, USA, 1996. 359 p.

PIRT, S. J. The maintenance energy of bacteria in growing cultures. Proceedings of the Royal Society B, v.163, p.224-231, 1965. http://dx.doi.org/doi:10.1098/rspb.1965.0069

ROBINSON, P. H. Impacts of manipulating ration metabolizable lysine and methionine levels on the performance of lactating dairy cows: A systematic review of the literature. Livestock Science, v. 127, n. 2, p. 115-126, 2010. http://dx.doi.org/doi:10.1016/j.livsci.2009.10.003

SATTER, L. D.; SLYTER, L. L. Effect of ammonia concentration on rumen microbial protein production in vitro. British Journal Nutrition. v. 32, p. 199-208, 1974. http://dx.doi.org/doi: 10.1079/BJN19740073

SIDDONS, R. C.; PARADINE, J. Effect of diet on protein degrading activity in the sheep rumen. Journal of the Science of Food and Agriculture. v. 32, p. 973-981, 1981. http://dx.doi.org/doi: 10.1002/jsfa.2740321005

SILVA, L. F. C.; VALADARES FILHO, S. C.; CHIZZOTTI, M. L.; ROTTA, P. P.; PRADO, L. F.; VALADARES, R. F. D.; ZANETTI, D.; BRAGA, J. M. S. Creatinine excretion and relationship with body weight of Nellore cattle. Brazilian Journal of Animal Science, v. 41, p. 807-810, 2012. http://dx.doi.org/doi:10.1590/S1516-35982012000300046

SNIFFEN, C. J.; O'CONNOR, J. D.; VAN SOEST, P. J.; FOX, D. G.; RUSSELL, J. B. A net carbohydrate and protein system for evaluating cattle diets: II. Carbohydrate and protein availability. Journal of Animal Science, v. 70, n.10, p.3562-3577, 1992. http://dx.doi.org/doi:10.2527/1992.70113562x

SNIFFEN, C. J.; ROBINSON, P. H. Microbial growth and flow as influenced by dietary manipulations. Journal of Dairy Science, v. 70, n. 2, p. 425-441, 1987. https://doi.org/10.3168/jds.S00220302(87)80027-9

SOUZA, D. P.; CAMPOS, J. M. S.; VALADARES FILHO, S. C.; VALADARES, R. F. D.; SEDIYAMA, C. A. Z.; CRUZ, J. C. C. Fermentative parameters, microbial protein production, plasma and milk urea concentration and nitrogen balance of milking cows fed maize silage or sugarcane with whole cottonseed. Brazilian Journal of Animal Science. v.38, n.10, p.2063-2071, 2009. http://dx.doi.org/doi:10.1590/S151635982009001000029

VAGNONI, D. B.; BRODERICK, G. A.; CLAYTON, M. K.; HATFIELD, R. D. Excretion of purine derivatives by Holstein cows abomasally infused with incremental amounts of purines. Journal Dairy Science, v. 80, p. 1695-1702, 1997. http://dx.doi.org/doi:10.3168/jds.S0022-0302(97)76101-0

VAN SOEST, P. J. Nutritional ecology of the ruminants. 2.ed., Ithaca: Cornell University. 1994. 476p. 
VERBIC, J.; CHEN, X. B.; MACLEOD, N. A.; ORSKOV, E. R. Excretion of purine derivatives by ruminants:Effect of microbial nucleic acid infusion on purine derivative excretion by steers. Journal of Agricultural Science. v. 114, p. 243-248, 1990. http://dx.doi.org/doi:10.1017/S0021859600072610.

VIEIRA, P. F. Efeito do formaldeído na proteção de proteínas e lipídios em rações para ruminantes. 1980.98 f. Tese (Doutorado em Zootecnia) - Curso de Pós-graduação em Zootecnia, Universidade Federal de Viçosa, Viçosa, 1980.

WELD, K. A.; ARMENTANO, L. E. The effects of adding fat to diets of lactating dairy cows on total-tract neutral detergent fiber digestibility: A meta-analysis. Journal of dairy science, v. 100, n. 3, p. 1766-1779, 2017. http://dx.doi.org/doi:10.3168/jds.2016-11500

YAN, T.; FROST, J. P.; KEADY, T. W. J.; AGNEW, R. E.; MAYNE, C. S. Prediction of nitrogen excretion in feces and urine of beef cattle offered diets containing grass silage. Journal Animal Science. v. 85, p. 19821989, 2007. http://dx.doi.org/doi:10.2527/jas.2006-408 